\title{
154. Experimentelle und klinische Erfahrung mit einem humanen Fibrinklebesystem in der Gefäßchirurgie
}

\author{
H.-W. Menges, W. Brands und P. Pfiester ${ }^{1}$ \\ Chirurgische Klinik (Dir.: Prof. Dr. Trede) und ${ }^{1}$ Pathologisches Institut (Dir.: Prof. Dr. Bleyl) \\ des Klinikum Mannheim der Universität Heidelberg, Theodor-Kutzer-Ufer, D-6800 Mannheim
}

\section{Experimental and Clinical Experiences With Human Fibrin-Gluing System in Vascular Surgery}

Summary. A comparative study in $13 \mathrm{dogs}$ of conventional suture and fibrin gluing in anastomoses of the carotid artery showed that gluing results in more physiological healing and the absence of necrosis of the wall, which is usually caused by suture material. As an analogue to this, we found no stenosis after 2 years in 25 patients with glued atrioventricular shunts. It was demonstrated by electromicroscopy that these highly porous prostheses have good primary sealing and healing and thus may be a new approach in patients with a tendency to hemorrhage.

Key words: Fibrin adhesive system - Bloodless preclotting - Combined suture and gluing - Atrioventricular fistulas.

Zusammenfassung. Die mikroskopische Vergleichsuntersuchung genähter und fibringeklebter Carotisanastomosen bei 13 Hunden zeigt eine physiologischere Anastomosenheilung des geklebten Gefäßes, da nahtbedingte Wandnekrosen vermieden werden. Analog dazu fanden wir bei 25 Patienten mit geklebten AV-Shunts keine Anastomosenstenosen nach 2 Jahren. Rasterelektronenoptisch konnte bei 13 Hunden eine verbesserte Einheilung und optimale Abdichtung fibrinpräparierter hochporöser Prothesen nachgewiesen werden, so daB die Anwendung dieses Verfahrens am blutungsgefährdeten Patienten einen neuen Weg aufzeigt.

Schlïsselwörter: Fibrinklebung - Abdichtung von Gefäßprothesen - AV-Shunts.

\section{Veränderung des Säure-Basen-Status, Lactat- und Purinemetabolismus bei Gefäßoperationen}

\author{
M. Schoenberg ${ }^{1}$, B. Fredholm ${ }^{2}$ und G. Hohlbach ${ }^{1}$ \\ ${ }^{1}$ Medizinische Hochschule Lübeck, Klinik für Chirurgie (Direktor: Prof. Dr. F. W. Schildberg), \\ Ratzeburger Allee 160, D-2400 Lübeck und \\ ${ }^{2}$ Farmakologiska Institutet, Karolinska Institutet, Stockholm, Schweden
}

\section{Changes in the Acid Base Status, Lactate and Purine Metabolism During Reconstructive Aortic Surgery}

Summary. Hypoxia is normally determined by the acid base status as well as by the lactate and pyruvate levels. These parameters, however, are not specific. Animal experiments showed that hypoxanthine is a specific indicator for hypoxia. Therefore, changes in the acid base status of lactate and purine metabolism were measured in 17 patients undergoing reconstructive aortic surgery. Blood samples were taken just before and after declamping of the aorta systemically and from the v. femoralis. After declamping, the systemic hypoxanthine levels increased 3-fold due to a 20-times-higher hypoxanthine concentration in the v. femoralis. The percentage of concentration changes of hypoxanthine correlated nicely with aorta clamping time. The changes in acid-base status and lactate levels were erratic and showed no correlation with the ischemic period. Systemic hypoxanthine concentrations are a specific and more reliable parameter for hypoxic damage.

Key words: Aortic surgery - Acid base status - Lactate - Purines.

Zusammenfassung. Gewebshypoxie wird üblicherweise am Säure-Basen-Status sowie an Lactat- und PurineKonzentrationen gemessen. Diese Parameter sind nicht spezifisch. Tierexperimentell konnte gezeigt werden, daß Hypoxanthin ein spezifischer Indikator für Hypoxie ist. Deshalb wurde an 17 Patienten mit gefäßrekonstruktiven Eingriffen an der abdominellen Aorta entsprechende Untersuchungen durchgeführt. Syste- 